\section{BIBLIO COUNS}

Biblio Couns I Jurnal Kajian Konseling dan Pendidikan

Vol. 1, No. 1, 2018, hlm. 29-34

Tersedia Online di jurnal.umsu.ac.id/index.php/biblio

ISSN 2620-3103 (online)

DOI: https://doi.org/10.30596/bibliocouns.v1i1.1942

\title{
Kontribusi Kecerdasan Emosional Terhadap Interaksi Sosial Mahasiwa
}

\author{
Yogi Damai Syaputra ${ }^{1}$, Monalisa ${ }^{2}$, \\ ${ }^{1}$ Jurusan Bimbingan dan Konseling IAIN Batusangkar \\ Jalan Jenderal Sudirman No.137, Lima Kaum, Kabupaten Tanah Datar \\ ${ }^{2}$ Prodi Bimbingan dan Konseling STKIP PGRI Sumatera Barat \\ Jalan Gunung Pangilun, Gunung Pangilun, Padang Utara \\ Korespondensi: yogi.ds@iainbatusangkar.ac.id
}

\begin{abstract}
The background of this research was the importance of a college students' guidance and counseling program in STKIP PGRI West Sumatera to have a good social interaction. Emotional intelligence became factors that can predict affect social interaction. The purpose of this research was obviously to describe: (1) emotional intelligence, (2) the contribution of emotional intelligence towards social interactions, This research was using quantitative method with correlation type. The population was college students' guidance and counseling program in STKIP PGRI West Sumatera in academic year 2012, 2013, 2014, and 2015. A number of college students were 818 students. The sample was 272 students selected by proportional stratified random sampling technique. The instrument was a Likert scale models. The research findings shown that: (1) an average of the emotional intelligence of college students at the high category, (2) there was a significant contribution of emotional intelligence toward social interaction.Implications of these results can be used as an analysis of the college students' needs in the preparation of guidance and counseling program services at universities, especially in STKIP PGRI West Sumatera.
\end{abstract}

Keywords: Emotional Intelligence, Social Interaction

Abstrak: Penelitian ini dilatarbelakangi oleh pentingnya mahasiswa program studi bimbingan dan konseling memiliki interaksi sosial yang baik. Kecerdasan emosional faktor yang diduga mempengaruhi interaksi sosial tersebut. Penelitian ini bertujuan untuk mendeskripsikan: (1) kecerdasan emosional, (2) kontribusi kecerdasan emosional terhadap interaksi sosial. Penelitian ini menggunakan metode kuantitatif jenis deskriptif korelasional. Populasi penelitian adalah mahasiswa program studi bimbingan dan konseling STKIP PGRI Sumatera Barat tahun masuk 2012, 2013, 2014, dan 2015 sebanyak 818 orang. Sampel sebanyak 272 orang, dipilih dengan teknik Proportional Stratified Random Sampling. Instrumen yang digunakan adalah skala model Likert. Temuan penelitian memperlihatkan bahwa: (1) secara ratarata gambaran kecerdasan emosional mahasiswa berada pada kategori tinggi, (2) terdapat kontribusi kecerdasan emosional secara signifikan terhadap interaksi sosial sebesar.Implikasi hasil penelitian tersebut dapat dijadikan sebagai analisis kebutuhan mahasiswa dalam penyusunan program pelayanan bimbingan dan konseling di perguruan tinggi, khususnya STKIP PGRI Sumatera Barat.

Katakunci: Kecerdasan Emosional, Interaksi Sosial 


\section{PENDAHULUAN}

Manusia adalah makhluk sosial yang dapat berinteraksi satu sama lain. Sepanjang rentang kehidupan yang dijalani, dari lahir hingga tutup usia manusia membutuhkan orang lain. Bermacammacam cara dalam proses interaksi akan banyak ditemui sepanjang manusia menjalani kehidupannya. Satu pribadi dengan pribadi lainnya, satu lingkungan dengan lingkungan lainnya akan memiliki cara yang berbeda dalam berinteraksi.

Semakin tinggi tingkat pendidikan, akan membuat seseorang berada pada lingkungan yang lebih luas. Perguruan tinggi merupakan lembaga pendidikan tertinggi yang dapat ditempuh oleh seseorang. Belajar di perguruan tinggi akan mempertemukan individu-individu yang berasal dari latar belakang berbeda. Memenuhi tugas dan tanggung jawab sebagai mahasiswa tentu membutuhkan kehadiran orang lain. Bertemu dengan individu baru, pada umumnya berasal dari latar belakang pendidikan, kampung halaman, budaya, agama dan bahasa yang berbeda menjadi masalah tersendiri yang dialami mahasiswa. Perbedaan tersebut tentu akan menimbulkan hal yang positif bila mahasiswa mampu mengatasinya dengan baik. Sebaliknya, akan menimbulkan hal yang negatif bila tidak mampu menanggapinya dengan baik. Dampak negatif dari perbedaan itu dapat diminimalisir apabila mahasiswa mampu menjalin interaksi sosial yang baik dengan lingkungannya.

Interaksi sosial yang dialami mahasiswa tentu tidak hanya interaksi sosial biasa, haruslah berkualitas dan dapat bermanfaat bagi orang lain. Menurut Bonner (dalam Ahmadi, 2007:49) interaksi sosial adalah suatu hubungan antara dua individu atau lebih, di mana kelakuan individu yang satu mempengaruhi, mengubah, atau memperbaiki kelakuan individu yang lain atau sebaliknya. Gerungan (2009:62) menyatakan bahwa hubungan antara individu yang berinteraksi senantiasa merupakan hubungan timbal-balik, saling memberikan pengaruh timbal balik. Berdasarkan pendapat tersebut, maka dapat disimpulkan bahwa interaksi sosial adalah kumpulan tingkah laku individu yang akan membentuk hubungan antara satu individu dengan individu lainnya di mana hubungan tersebut dapat memperbaiki, mengubah atau mempengaruhi individu lainnya.

Interaksi sosial akan berbeda pada setiap lingkungan yang dilalui oleh mahasiswa. Warsito (dalam Sumiyatun, 2003:144) menyatakan bahwa pertemuan beberapa kelompok dapat membuahkan hal yang bersifat positif dan negatif sebagai perwujudan dari interaksi sosial. Hal yang positif akan terjadi bila setiap individu mampu untuk saling menerima dan menghargai. Sebaliknya, akan bersifat negatif bila tidak adanya rasa saling menerima dan menghargai. Al-Munawir (dalam Muslim, 2013:484) menyatakan bahwa manusia adalah individu yang selalu ingin melakukan kerjasama dan interaksi sosial. Lebih lanjut, Muslim (2013:484) menyatakan bahwa interaksi tersebut tidak hanya dipicu oleh dorongan kebutuhan ekonomis, biologis, emosional, dan sebagainya yang mengikat dirinya, melainkan juga sebagai fitrah yang 
tidak terbantahkan pada dirinya. Mengutip pendapat tersebut, diketahui bahwa interaksi sosial yang terjadi salah satunya dipengaruhi oleh kecerdasan emosional seseorang.

Menurut Ma'sum (dalam Yunistiati, Djalali, dan Farid, 2014:80) bahwa interaksi sosial dipengaruhi oleh pola asuh demokratis, lintas budaya, model kepribadian, regulasi emosi, rasionalitas, hubungan sosial yang diharapkan, pembangunan sosial yang diharapkan dan pemikiran sosial. Penelitian yang dilakukan oleh Lopes, Brackett, Nezlek, Shiitz, Sellin, dan Salovey (2004) diketahui bahwa kecerdasan emosional yang dimiliki seseorang memiliki pengaruh yang positif terhadap kualitas interaksi sosialnya.

Berdasarkan pendapat tersebut, jelaslah bahwa banyak faktor yang mempengaruhi interaksi sosial, dua diantaranya adalah kecerdasan emosional. Namun, untuk mengetahui seberapa besar kontribusi yang diberikan oleh faktor tersebut terhadap interaksi sosial perlu dilakukan penelitian. Tujuan penelitian ini adalah untuk mendeskripsikan: (1) kecerdasan emosional mahasiswa Program Studi Bimbingan dan Konseling STKIP PGRI Sumatera Barat, (2) kontribusi kecerdasan emosional terhadap interaksi sosial mahasiswa Program Studi Bimbingan dan Konseling STKIP PGRI Sumatera Barat.

\section{METODE}

Penelitian ini menggunakan metode kuantitatif jenis deskriptif korelasional. Populasi penelitian adalah mahasiswa Program Studi Bimbingan dan Konseling STKIP PGRI Sumatera Barat yang bejumlah 818 mahasiswa, dengan sampel 272 mahasiswa yang dipilih dengan teknik proportional stratified random sampling. Instrumen yang digunakan adalah skala model Likert. Untuk mengetahui kontribusi variabel bebas terhadap variabel terikat, maka data dianalisis dengan regresi sederhana. Analisis data dibantu dengan menggunakan program SPSS versi 20.00.

\section{HASIL}

Untuk mengetahui ada tidaknya hubungan antara kontribusi kecerdasan emosional terhadap interaksi sosial mahasiswa maka telah dilakukan uji hipotesis. Adapun hasil uji hipotesis yang dilakukan sebagai berikut:

\section{Kontribusi Kecerdasan Emosional terhadap Interaksi Sosial Mahasiwa}

Untuk menguji hipotesis ada tidaknya kontribusi kecerdasan emosional terhadap interaksi sosial mahasiswa maka dilakukan uji regresi sederhana, adapun hasil pengujiannya disajikan dalam tabel 1 berikut: 
Tabel 1 Hasil Perhitungan Pengujian Koefisien Korelasi Variabel X terhadap Y

\begin{tabular}{lcccc}
\hline \multicolumn{3}{c}{ Model Summary } & & \\
\hline Model & $\mathrm{R}$ & $\mathrm{R}$ Square & $\begin{array}{c}\text { Adjusted R } \\
\text { Square }\end{array}$ & $\begin{array}{c}\text { Std. Error of } \\
\text { the Estimate }\end{array}$ \\
\hline 1 & .290 &, 084 &, 081 & 6,939 \\
\hline a.Predictors: (Constant), Kecerdasan Emosional & &
\end{tabular}

Berdasarkan tabel di atas hasil yang diperoleh dalam penelitian ini, nilai R sebesar 0.290 dan nilai R Square (R2) sebesar 0.084. Artinya, terdapat kontribusi X terhadap Y, dan X terhadap Y adalah sebesar $8,4 \%$.

Tabel 2 Hasil Pengujian Signifikansi Koefisien Regresi Variabel X terhadap Y ANOVA $^{b}$

\begin{tabular}{ll|l|l|c|c|c}
\hline Model & & Sum of Squares & Df & $\begin{array}{c}\text { Mean } \\
\text { Square }\end{array}$ & F & Sig. \\
\hline 1 & Regression & 1191,209 & 1 & 1191,209 & 24,740 & $.000^{\mathrm{a}}$ \\
& Residual & 12999,111 & 270 & 48,145 & & \\
& Total & 14190,320 & 271 & & & \\
\hline
\end{tabular}

a. Predictors: (Constant), Kecerdasan Emosional

b. Dependent Variable: Interaksi Sosial

Tabel di atas menjelaskan nilai $F_{\text {hitung }}$ adalah 24.740 , sedangkan $F_{\text {tabel }}$ adalah 3.89 , artinya $F_{\text {hitung }}>$ $\mathrm{F}_{\text {tabel }}$ dengan signifikansi $0.001<0.05$. Dengan demikian, dapat dinyatakan bahwa kecerdasan emosional dapat memprediksi besarnya angka-angka variabel interaksi sosial mahasiswa.

Tabel 3 Hasil Perhitungan Persamaan Regresi Variabel X terhadap Y Coefficients $^{\mathbf{a}}$

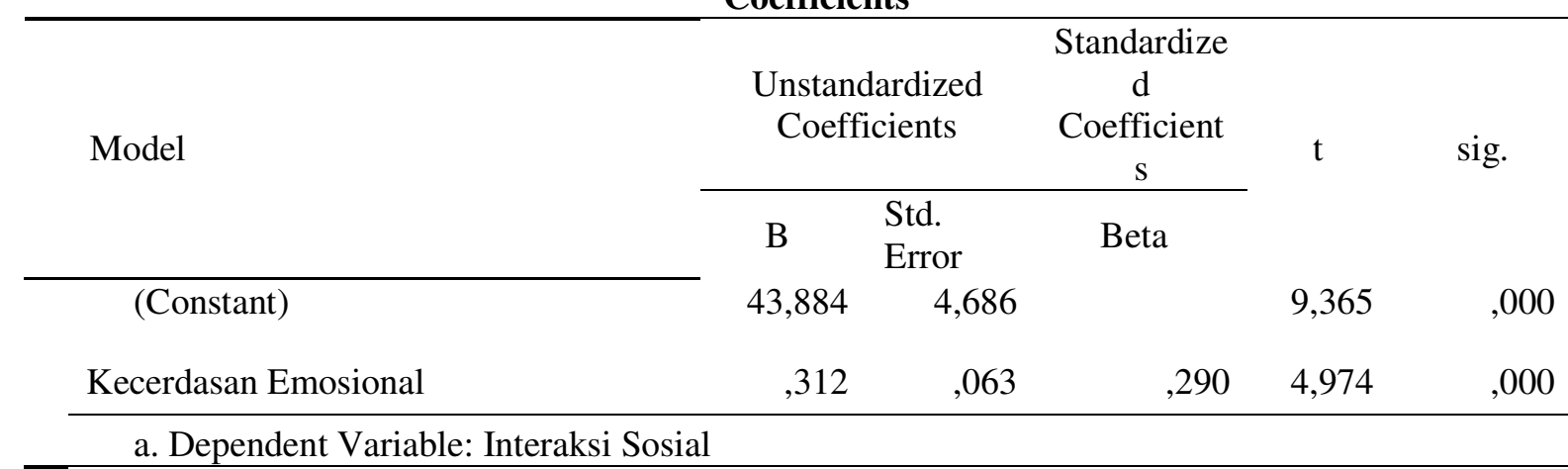

Hasil regresi sederhana pada tabel di atas menunjukkan bahwa thitung sebesar 4.974, sedangkan $t_{\text {tabel }}$ sebesar 1.960 , berarti $t_{\text {hitung }}>t_{\text {tabel. }}$. Hal ini berarti, bahwa terdapat kontribusi yang signifikan antara kecerdasan emosional terhadap interaksi sosial mahasiswa. Tabel 3 di atas juga menunjukkan persamaan regresi sebagai berikut. $\tilde{Y}=43,884+0.312 X$ 


\section{PEMBAHASAN}

Hasil penelitian menunjukkan bahwa kecerdasan emosional berkontribusi secara signifikan terhadap interaksi sosial. Temuan ini diperoleh berdasarkan hasil analisis data yang menunjukkan bahwa kontribusi kecerdasan emosional terhadap interaksi sosial sebesar 8,4\%. Artinya, kecerdasan emosional merupakan salah satu faktor yang berkontribusi terhadap interaksi sosial. Kemampuan seseorang dalam mengelola suasana hatinya akan menentukan bagaimana seseorang tersebut bersikap yang pada akhirnya akan membuat suatu interaksi dengan orang lain. Karena, kebanyakan orang hanya bersedia menolong orang lain saat perasaan hatinya sedang baik dari pada saat perasaan hatinya tidak baik, (Baron, Berkowitz dalam Baron dan Byrne, 2004:39).

Lopes, Salovey, Cote dan Beers (2005:113) menyatakan bahwa "One inappropriate outburst of anger can destroy a relations forever". Hal tersebut dapat dimaknai bahwa, salah satu ledakan kemarahan yang tidak tepat dapat menghancurkan hubungan selamanya. Terlihat bahwa, kecerdasan emosional seseorang berdampak terhadap hubungan orang itu sendiri. Terjalinnya suatu interaksi sosial yang berkualitas tentu banyak faktor yang mempengaruhinya, salah satunya adalah kecerdasan emosional. Goleman (2007:48) menyatakan bahwa orang yang cakap secara emosional, mengetahui dan dapat dengan baik menangani perasaan mereka sendiri, serta mampu dengan tepat menghadapi perasaan orang lain, memiliki keuntungan dalam setiap bidang kehidupan, entah itu dalam hubungan asmara dan persahabatan yang mereka jalin, ataupun dalam menangkap aturan-aturan tidak tertulis yang menentukan keberhasilan dalam politik organisasi. Dapat dikatakan bahwa, seseorang yang memiliki dan dapat mengembangkan dengan baik kecerdasan emosionalnya mampu membangun hubungan yang baik dengan orang lain, apakah hubungan tersebut dinamakan hubungan asmara, pertemanan, persahabatan ataupun dengan kolega dalam kegiatan politik organisasi yang mereka geluti.

Hasil penelitian ini juga sesuai dengan pendapat Lopes, Salovey, Cote, dan Beers (2005:113) yang menyatakan bahwa kemampuan seseorang dalam mengelola emosinya memainkan peranan penting dalam interaksi sosial seseorang. Lopes, Salovey, Cote, dan Beers (2005:113) juga menyatakan bahwa "Emotion regulated ability correlated significantly with four out of eight indicators of the quality of sosial interactions". Berdasarkan pendapat tersebut, jelaslah bahwa kecerdasan emosional seseorang memberikan kontribusi terhadap interaksi sosialnya. Mahasiswa haruslah memiliki kecerdasan emosional yang tinggi, agar dapat membangun interaksi sosial yang baik dengan sispapun dan dimanapun. Pengembangan aspek kecerdasan emosional dapat diberikan oleh kampus terhadap mahasiswa melalui layanan bimbingan dan konseling. 


\section{SIMPULAN}

Kecerdasan emosional memberikan kontribusi secara signifikan terhadap interaksi sosial mahasiswa. Artinya, semakin baik seseorang dalam mengelola emosinya, semakin baik jugalah kemampuan seseorang tersebut dalam membangun interaksi sosialnya. Penelitian ini masih secara umum mengukur kecerdasan emosional, belum dilihat bagaimana perbedaan mahasiswa laki-laki dan perempuan dalam mengelola kecerdasan emosionalnya. Terlebih, interaksi sosial yang dimaksudkan disini masih terbatas kepada interaksi mahasiswa dalam proses perkuliahan. Untuk itu, dapat dilanjutkan penelitian secera lebih luas lagi.

\section{DAFTAR RUJUKAN}

Ahmadi, A. 2007. Psikologi Sosial. Jakarta: Rineka Cipta.

Baron, R.A, dan Byrne, D. 2004. Social Psychology. Understanding Human Interaction. Boston: Allyn and Bacon, Incorporation.

Gerungan. 2009. Psikologi Sosial. Bandung: Refika Aditama.

Goleman, D. 2007. Emotional Intelligence, Mengapa EI Lebih Penting dari pada IQ. (Alih Bahasa: T. Hermaya). Jakarta: Gramedia Pustaka Utama.

Lopes, P.N., Brackett, M.A., Nezlek, J.B., Schiitz, A., Sellin, I., dan Salovey, P. 2004. "Emotional Intelligence and Social Interaction". Personality and Social Psychology Bulletin. 30. 1018-1034.

Lopes, P.N., Salovey, P., Cote, S., dan Beers, M. 2005. "Emotion Regulation Abilities and the Quality of Social Interaction". Brief Reports American Psychological Association. 113-118.

Muslim, A. 2013. "Interaksi Sosial dalam Masyarakat Multietnis". Jurnal Diskursus Islam. Volume 1 Nomor 3. Desember 2013.

Sumiyatun. 2003. "Interaksi Sosial Etnis Jawa dengan Penduduk Asli Lampung (Studi tehadap Masyarakat Kota Metro, Provinsi Lampung)". Tesis tidak diterbitkan. Padang: Pogram Pascasarjana UNP. 